\title{
Corporate Social Sustainability Reporting and Financial Performance of Oil and Gas Industry in Nigeria
}

\author{
Erhirhie Felix Erhinyoja*, Ekwueme Chizoba Marcella \\ Department of Accountancy, Faculty of Management Sciences, Nnamdi Azikiwe University, Awka, Nigeria \\ Email address: \\ felixerhirhie $a$ yahoo.com (F. E. Erhirhie), cm.ekwuemecm $a$ unizik.edu.ng (E. C. Marcella) \\ ${ }^{*}$ Corresponding author
}

\section{To cite this article:}

Erhirhie Felix Erhinyoja, Ekwueme Chizoba Marcella. Corporate Social Sustainability Reporting and Financial Performance of Oil and Gas Industry in Nigeria. International Journal of Accounting, Finance and Risk Management. Vol. 4, No. 2, 2019, pp. 44-60.

doi: 10.11648/j.ijafrm.20190402.12

Received: March 13, 2019; Accepted: April 17, 2019; Published: July 4, 2019

\begin{abstract}
This study examined corporate social sustainability reporting and financial performance of Oil and Gas Industry in Nigeria. Issues regarding corporate sustainability have gained global relevance in recent times owing to the increasing awareness that activities of most organizations may have adverse implicational effects on the ecosystems, societies, and environments of the future. Thus, companies are now being required to extend their strategic policies and information reportage to encompass sustainability reporting practices in order to meet the environmental and social needs of both current and future stakeholders. It is on this light that this study was set out to examine the effect of sustainability reporting on the financial performance of listed oil and gas companies in Nigeria. This study assessed the effect of corporate social sustainability reporting on Return on Assets, Return on Equity, and Return on Capital Employed of oil and gas companies listed on the Nigeria Stock Exchange. Ten oil and gas companies were sampled for the study. The study utilized secondary data collected via financial ratios and accounts of the individual companies and content analysis. The findings showed that social sustainability reporting exerts negative effect on all three performance proxies, howbeit only its effect on return on equity was statistically significant. The study recommends, among others, that existing sustainability reporting standards should be aligned to reflect country-specific social and environmental challenges, while its implementation should rather be obligatory rather than voluntary.
\end{abstract}

Keywords: Social Sustainability Reporting, Return on Assets, Return on Equity,

Capital Employed and Oil and Gas Industry

\section{Introduction}

Maximizing shareholders' interests have traditionally dominated the corporate strategy of many organizations in time past. The apparent reason been that since the management (agents) runs the affairs of the organization on behalf of the owners (principals), the major interest of the latter (profit maximization) would often be considered paramount in order for the business to retain its capital. However, happenings in the last decade, such as concerns on global warming and the likes, demand that since the activities of most business organizations may have adverse environmental degradation effect on humans and its environments, companies may need to soft-pedal on the narrow version of classical economic theory and embrace sustainable corporate strategies that include goals that go beyond just maximizing shareholders' interest [1].

In line with the foregoing, companies world over are increasingly being challenged to extend their accounting information reportage to encompass sustainability reporting practices as part of their corporate strategy and competitive advantage [2]. Aside adequate financial capital, companies also require strong governance and workplace practice that recognizes environmental and social needs of current and future stakeholders for it to achieve long term sustainability. PricewaterhouseCoopers stated that recognizing and incorporating such social and environmental factors into the governance and strategic operations of the firm is referred 
to as Corporate Sustainability (CS). In essence, corporate sustainability entails aligning the competitive activities of the organization to meeting the short-term needs of the current stakeholders without jeopardizing the long-term ability of future stakeholders in meeting their own needs, thereby adding economic, environmental and social values [3]. These three lines of values (Tripple bottom line), according to Asaolu, Agboola, Ayoola and Salawu which are targeted at the economy, society and environment respectively [4]

Studies on the effect of corporate sustainability on the overall performance of listed corporations have gathered momentum in recent times. The reasons are quite understandable considering the state of the world's environment and the adverse effect of most organizations' activities on the ecology of host communities leading to increased public concern and criticism due to some socially irresponsible firms. Ejoh, Orok and Sackey noted that it was no good having great corporate profits and material wellbeing if they come at the cost of large scale of ecosystem by which humans and environment are negatively affected [5]. Thus, the tenets of corporate sustainability demand that companies should be responsible for the consequential environmental and social impact which their activity incurs on the environment of host communities and other stakeholders, assuming such responsibilities will go a long way in pacifying the long-run losses likely to be borne by the stakeholders of the immediate environment where the companies operate. As Kwaghfan puts it, "business is central to the (environmental) problem and must be central to the solution" [6].

In Nigeria for instance, one sector of the economy that has attracted a lot of public outcry on issues relating to environmental concerns is the oil and gas Industry. This sector is a major source of revenue to the Nigerian State. Their activities are often associated with severe health implications and environmental degradation which in recent past have caused nagging social disputes and disruption of some multinational companies' economic activities [7]. The concerns are been heightened due to stakeholders and host community's increased awareness of environmental degradation issues such as air and water pollution from heavy industrial machines, lack of clean-fresh water, lack of sea foods due to oil spill, and the likes. The need for sustainable environmental cost management in the oil and gas sector has thus become the concern and focus of most nations and responsible corporate managements the world over. Organizations are now expected to be able to demonstrate that they are aware and addressing the impact of their operations on the environment and society in general [8].

With regards to recent studies by Nigerian authors, researchers like $[2,69,10,11,12,13]$ found that sustainability reporting has positive and significant effect on financial performance of listed firms; while others like $[14,15,16,17]$ found that corporate sustainable development practices of companies are rarely associated (non-significant effect) with profitability of listed companies. Based on these contradictory empirical outcomes, it appears evident that the question of whether or not corporate sustainability practices affect firm performance remains an open question.

Going further, several reasons could be attributed to these observed inconsistencies in prior studies. Excluding the fact that country-specifics and other peculiarities may influence the outcome of studies conducted in both developed and developing countries because of divers ways corporations respond to environmental and social concerns in different climes, a look at the most previous studies particularly those by Nigerian authors shows a large domination of samples comprising only of a single sub-sector and or a sub-set of a particular sector with the most current data being that of 2014 [2]. For example, the recent studies of [9] and [14] focused on just two and one oil and gas companies respectively; while Bassey, Oba \& Onyah [13] focused on the oil and gas industry but adopted a time series data approach. Others Nnamani et al [2] focused on only three (3) Brewery companies, Owolabi et al [10] sampled only one industrial company (i.e. Lafarge Plc), Nwobu [15] focused on only Nigerian banks, while Okoye and Ezejiofor [12] limited their sample to just two (2) manufacturing companies, and so on.

Another reason for the lack of convergence identified among the previous studies is the pattern of financial performance measures adopted. Most of the previous studies, such as employed just one category of financial performance, which may not capture other dimensions of company financial performance indicators[11, 15],. Thus, in line with the recommendations of Nwobu [15] that future studies should expand the sample size in order to improve the results of existing studies, there is a possibility that conducting an updated research encompasses all listed oil and gas companies in a panel based study using the most current available data with complete information for a period of ten financial years (2007 - 2016), and adopting three (3) different financial performance proxies (ie) Return on Asset, Return on Equity, and Return on Capital Employed would go a long way in reconciling the observed conflicting evidences in prior studies.

The study assessed the effect of Corporate Social Sustainability reporting on financial performance of oil and gas companies listed in the Nigerian Stock Exchange (NSE). Specifically, the study has the following as its objectives:

To examine the effect of Corporate Social Sustainability Reporting on Return on Assets (ROA) of Oil and Gas companies listed on the Nigerian Stock Exchange;

To determine the extent to which Corporate Social Sustainability Reporting affects Return on Equity (ROE) of Oil and Gas companies listed on the Nigerian Stock Exchange;

To ascertain the effect of Corporate Social Sustainability Reporting on Return of Capital Employed (ROCE) of Oil and Gas companies listed on the Nigerian Stock Exchange; 


\section{Review of Related Literature}

\subsection{Corporate Sustainability VS Corporate Social Responsibility (CSR)}

According to Kalsson, corporate social responsibility (CSR) and corporate sustainability (CS) have all been used synonymously to describe the same business practices [18]. However, in many cases these phrases include different aspects of stakeholder activities, such as social, environmental, and/or economic and governmental factors [19]. Corporate social responsibility (CSR) has long been a popular phrase to describe business activities aimed at stakeholder-interests. However, despite numerous attempts, no consensus has been reached regarding its definition and what the term actually encompasses. For instance, a common division is to only attribute it with social factors, thus disregarding other aspects, such as the environmental impact. This has contributed to criticism against the use of the term, which also extends to its main focus on philanthropic responsibility. Instead, sustainability (a successor to 'sustainable development') is rapidly becoming more popular in strategic management. Yet, as with corporate social responsibility, its meaning is often considered as vague and ambiguous, e.g. in some instances it is only associated with environmental issues $[19,20]$. However, the GRI Sustainability Reporting Guidelines explains that sustainability reporting is the practice of being accountable to both internal and external stakeholders of organizations by measuring and disclosing firms' performance in relation to the goal of sustainable development [21].

The Global Reporting Initiative (GRI) Sustainability Reporting Guidelines acknowledge that sustainability can be equated as CSR and define a sustainability report as "a report published by a company or organization about the economic, environmental, and social impacts caused by its everyday activities. Sustainability report also presents the organization's values and governance model and demonstrates the link between its strategy and its commitment to a sustainable global economy." This definition indicates that sustainability is not a one-time activity; it must be built into an organization's overall philosophy and strategy.

A major difference between sustainability and CSR (as well as corporate citizenship and triple bottom line) is their relation to time. According to Bansal and DesJardine, a sustainable business is one "that manage inter-temporal trade-offs in strategic decision making, so that both the short and long-term is considered" [19]. Thus, companies need to decide between either investing less to secure smaller profits faster and or investing more to receive greater profits in the future [22]. Corporate social responsibility on the other hand does not automatically necessitate trade-offs, but is instead often related to ideas, such as 'shared value' and 'win-win'situations. In these situations businesses and society is believed to gain instant and simultaneous value from a corporation's actions [23]. Therefore, since sustainability - in comparison with its related terms - to a greater extent considers the complexity of balancing short- and long-term decisions, the following thesis will hereafter use the term sustainability (including environmental, social, and governmental factors) when referring to business stakeholder activities.

\subsubsection{Sustainability and Social Issues}

The social dimension of sustainability concerns the impacts an organization has on the social systems such as labour practices, human rights and relationship with communities within which it operates. The indicators surround around labour practices and decent work, human rights, society and product responsibility [24].

Profit is considered as the primary motive of profitoriented business organizations operating especially in the private sector. In actualizing this objective, companies usually minimize the costs associated with business activities and maximize their profits. Even though scarce resources are used by businesses for production, 'sustainability' is a call for consideration of social good in carrying out production activities. Responsibility towards social justice issues is the ability of a firm to take actions and be accountable for its social and environmental impacts on the society. One of the ways through which this accountability is communicated is through sustainability reporting. With the multi-dimensional role of a corporation to the shareholders (providing them with a reasonable return on investment), state (payment of taxes), people (being socially responsible) and environment (reducing environmental impacts as a result of daily operations); it also connotes community development i.e. effort of the company to develop its immediate environment via community developmental policies, and involvement in issues such as sports, education, social amenities, infrastructural facilities and community health matters. Accountability for these roles is revealed through disclosures by firms in their corporate communication media. As long as a firm continues to exist, it will do so within the confines of the people who make up the society and the planet.

There are different opinions about the interaction between social performance (as a component of sustainability) and financial performance. The empirical research has not reached at a consensus. Earlier scholars such as Friedman [25] submit that social responsibility involves costs and therefore can worsen firms' performance, while Nze, Okoh \& Ojeogwu( show that CSR has a positive and significant effect on earnings of firms [26]. Murray argues that the practice of sustainable development by firms signals reduction in future earnings and erosion of investor's short-run returns [27]. Kwanbo [28] also found that corporate social disclosure is an insignificant tool to maximizing corporate objectives. A foremost corporate objective is the maximization of firm earnings. His study deduced that social disclosure has no impact on earnings per share. The implication of this finding is that business organizations may not be obliged to be responsible for issues pertaining to social justice. Hamilton, Jo and Statman noted that it is possible that markets do not 
value corporate social responsibility at all or markets value corporate social responsibility efficiently or markets do not value corporate social responsibility efficiently [29].

McWilliams, Siegel and Wright contend that "firms should pursue green management practices only when it is in their self-interest to do so" [30]. In this perspective, decisions regarding CS are considered as a form of strategic investment [30]. Preston and O'Bannon [26] attempted to discover if social and financial performance is positively correlated, negatively correlated, or not correlated at all. Additionally, they wish to determine if a casual relationship behind these factors exists. This means that social performance may drive financial performance, financial performance may influence social performance, or there is a synergistic relationship between the two. They discovered that there was not a single negative relationship between social and financial performance in large U.S. companies, which is consistent with the stakeholder theory. The strongest evidence indicated that social-financial performance is a positive synergy, meaning that available funds drive positive social performance and that positive social performance also drives financial performance [26].

Waddock and Graves also argue that attention to corporate social performance builds effective and lasting relationships with stakeholder groups, which causes better overall financial performance [31]. They attempted to discover if "there is a positive relationship between CSP and financial quality performance and whether slack resources and good management theory may be operating simultaneously" Their concluding theory is in line with Preston and O'Bannon, stating that this relationship is a virtuous cycle where firms perform well, increase corporate sustainability, and then performs even better [31].

According to NSE sustainability disclosure guidelines of December 2016, the core elements of Social performance include:

1. Businesses should respect the right to freedom of association, participation, collective bargaining, and provide access to appropriate grievance redress mechanisms.

2. Businesses should provide and maintain equal opportunities at the time of recruitment as well as during the course of employment irrespective of caste, creed, gender, race, religion, or disability.

3. Businesses should not use child labour, forced labour or any form of involuntary labour, paid or unpaid.

4. Businesses should take cognizance of the work-life balance of its employees, especially that of women.

5. Businesses should provide facilities for the wellbeing of its employees including those with special needs. They should ensure timely payment of fair living wages to meet basic needs and economic security of the employees.

6. Businesses should provide a workplace environment that is safe, hygienic humane, and which upholds the dignity of the employees. Business should communicate this provision to their employees and train them on a regular basis.

7. Businesses should ensure continuous skill and competence upgrading of all employees by providing access to necessary learning opportunities, on an equal and nondiscriminatory basis. They should promote employee morale and career development through enlightened human resource interventions.

8. Businesses should create systems and practices to ensure a harassment free workplace where employees feel safe and secure in discharging their responsibilities.

9. Businesses should systematically identify their stakeholders, understand their concerns, define purpose and scope of engagement, and commit to engaging with them.

10. Businesses should acknowledge, assume responsibility and be transparent about the impact of their policies, decisions, product and services, and associated operations on the stakeholders.

11. Businesses should give special attention to stakeholders in areas that are underdeveloped.

12. Businesses should resolve differences with stakeholders in a just, fair and equitable manner.

\subsubsection{Social Sustainability Measures}

Social variables refer to social dimensions of a community or region and could include measurements of education, equity and access to social resources, health and well-being, quality of life, and social capital. The examples listed below are a small snippet of potential variables [32].

Unemployment rate

Female labor force participation rate

Median household income

Relative poverty

Percentage of population with a post-secondary degree or certificate

Average commute time

Health-adjusted life expectancy

CSR entails giving back to the society some of the benefits and gains realized from the society. The desire of most organizations is to have a positive impact on the society where they are generating revenue. Helg stated that CSR has the potential to make positive contributions to the development of society and businesses [32]. Onwuegbuchi maintain that "CSR is the deliberate inclusion of public interest into corporate decision making and the honouring of a triple bottom line of people, planet and profit" [33]. In other words, CSR policy entails self-regulation, adherence to rules and regulations, ethical standards, environmental responsibility and sustainability, consumers' satisfaction, employee welfare, communities and stakeholders benefits. Dabbas and Al-rawashdeh, opined that Corporate Social Responsibility was not known clearly in the first half of the twentieth century, where corporations were trying to maximize their profits by all means [34]. Alkababji stated that Corporate Social Responsibility developed because of the expansion and globalization of the world economy which led to the emergence of multinational companies with economic power greater than the gross domestic product of many small or developing countries. Therefore, business activities correspondingly have a more extensive effect on 
society than ever before. In addition, with many developed countries recently experiencing severe financial crisis, society increasingly requires that companies take responsibility for environmental conservation, employment, safety, and local community development-areas that previously were primarily the responsibility of national governments [35].

Many of these measures are collected at the state and national levels, but are also available at the local or community level. Many are appropriate for a community to use when constructing a TBL. However, as the geographic scope and the nature of the project narrow, the set of appropriate measures can change. For local or communitybased projects, the TBL measures of success are best determined locally.

\subsubsection{Corporate Sustainability Reporting and Financial Performance}

Studies on financial performance in relation to sustainability disclosures are of two types. The first uses the event study methodology to assess the short-run financial impact (abnormal returns) when firms engage in either socially responsible or irresponsible acts. The second examines the relationship between corporate sustainability disclosures and financial performance by using accounting measures of profitability. The latter is the focus of this study. This sub-section discusses each of the three performance measures adopted for the study (Return on Assets (ROA), Return on Equity (ROE), and Return on Capital Employed (ROCE) - in relation to sustainability:

Return on Assets (ROA) and Sustainability

ROA gives profitability on assets of the firm after meeting all expenses and taxes. It measures the profit of the firm after tax for each dollar invested in assets [36]. It is an indicator of managerial performance. When assessing a business's financial fitness, it is important to know how successful it is at turning what it already has into additional profits for owners and shareholders. The ROA formula is a straightforward calculation, and its component parts are easily located on a company's financial statements. So, higher value of this ratio means better managerial performance [37]. ROA can be increased by increasing profit margin or asset turnover. This thesis uses the return on assets (ROA) as one of the proxies to measure financial performance. ROA is not only a standard measurement of corporate performance within corporate sustainability literature; it is also commonly used in the majority of strategy research [38]. ROA is calculated as the net profit in relation to total assets. This outcome gives an idea of what the company can do with what it has, i.e. how many additional earnings they derive from each amount of assets they control. It gives an indication of the capital intensity of the company, which will depend on the industry; companies that require large initial investments will generally have lower return on assets. ROAs over $5 \%$ are generally considered good.

Over the years, studies have been carried out to examine the association between corporate sustainability reporting and financial performance. According to Lopez, Garcia and Rodriguez, changes in management practices and disclosure should reflect in the profit and loss statement, produced by an increase in business volume, implying an increase in assets only in those companies which have adopted sustainable practices [39]. Epps and Cereola stated that the operating performance of a business organization can be measured using Return on Asset (ROA) which shows the amount of earnings generated from the resources owned by them [40]. According to Gozali et al, results linking profitability to ethical behavior are mixed [41]. Buys, Oberholzer and Andrikopoulos found that the economic performances of companies that voluntarily submit sustainability reports are better than those who do not support Global Reporting Initiatives (GRI) sustainability reporting guidelines. Accounting based studies appear to have a stronger positive link between sustainability reporting and financial performance than market based ones [42]. According to Gregory, Tharyan and Whittaker, this may be due to the inefficiency of stock markets or because accounting measures do not sufficiently account for risk [43]. A study of 60 manufacturing firms in Nigeria using Return on Total Assets (ROTA) as measure of performance showed a significant relationship between community development (CD) and performance., the result revealed a statistically significant relationship (at 5 percent level) between CD and ROA [44]. On the contrary, Eccles et al examined the impact of corporate sustainability on organizational processes and performance using ROA as proxy for financial performance [45]. Their outcome shows that the coefficients sustainability on ROA is insignificant, howbeit positive. This corroborates most previous arguments that engagement in sustainability may likely not lead to significant increase in financial performance.

B. Return on Equity (ROE) and Sustainability

One of the measures of financial performance includes Return on Equity (ROE). The ROE indicates the overall firm profitability or how much earnings are generated from the investment of shareholders (stockholders' money) in the equity of a business organization. Return on equity represents profitability of shareholders of the firm after meeting all expenses and taxes [36]. Higher ROE means better managerial performance. But higher ROE can be due to financial leverage. So higher levered firms may have higher ROE which increases risk too [37]. Usually ROE is higher for high growth companies; ROEs of $15-20 \%$ are generally considered good.

ROE is especially used for comparing the performance of companies in the same industry or firms in similar competitive environment. Roberts and Dowling argue that companies with good corporate reputation in their communities are better able to sustain their superior outcomes over other firms because their intangible character makes replication by competing firms considerably more difficult [46]. Adam and Zutshi suggested that firms' adoption of sustainable strategies should grant them competitive advantages over other firms where no such 
implementation occurs [47].

Previous studies such as Olayinka and Temitope empirically examined the relationship between corporate social responsibility and financial performance in Nigeria using Return on Equity (ROE) as profit performance. The result shows that CSR has a positive and significant relationship with the financial performance measure [48]. Yahya and Ghodratollah also investigated the impact of corporate social responsibility disclosure (CSRD) on the financial performance of companies listed on the Tehran stock exchange, employing multiple-linear regression analysis [49]. The CSRD was the independent variable as measured by economic, social and environmental while Return on Equity (ROE) and Price Earnings Ratio were used in measuring financial performance. The analysis though produced inconsistent results, suggesting that the impact of sustainability of ROE can go either way.

C. Return on Capital Employed and Sustainability

Return on capital employed (ROCE) is a financial ratio that measures a company's profitability and the efficiency with which its capital is employed. ROCE is calculated as: ROCE $=$ Earnings Before Interest and Tax (EBIT) / Capital Employed. "Capital Employed" as shown in the denominator is the sum of shareholders' equity and debt liabilities; it can be simplified as (Total Assets-Current Liabilities). Instead of using capital employed at an arbitrary point in time, analysts and investors often calculate ROCE based on "Average Capital Employed," which takes the average of opening and closing capital employed for the time period. A higher ROCE indicates more efficient use of capital. ROCE should be higher than the company's capital cost; otherwise it indicates that the company is not employing its capital effectively and is not generating shareholder value.

ROCE is especially useful when comparing the performance of companies in capital-intensive sectors such as utilities and telecoms. This is because unlike return on equity (ROE), which only analyzes profitability related to a company's common equity, ROCE considers debt and other liabilities as well. This provides a better indication of financial performance for companies with significant debt. Adjustments may sometimes be required to get a truer depiction of ROCE. A company may occasionally have an inordinate amount of cash on hand, but since such cash is not actively employed in the business, it may need to be subtracted from the "Capital Employed" figure to get a more accurate measure of ROCE. For a company, the ROCE trend over the years is also an important indicator of performance. In general, investors tend to favor companies with stable and rising ROCE numbers over companies where ROCE is volatile and bounces around from one year to the next [50].

Kurucz, Colbert and Wheeler identify four categories of benefits that firms may attain from engaging in corporate social responsibility activities: (1) cost reduction; (2) competitive advantage; (3) developing reputation and legitimacy; and (4) seeking win-win outcomes [51]. Efficient and reliable contracting with suppliers, employees, and creditors should also lead to lower contracting and monitoring costs for the sustainable firm compared to other firms, thereby increasing the return on capital employed [46]. Margolis, Elfenbein, and Walsh in their meta-analysis of 167 studies found evidence of a link between environmental dimension of CSR and firm performance [52]. The result has also been confirmed in a study of the value relevance of environmental performance of eighteen environmentally sensitive firms in Nigeria. Oba, Fodio and Soje used logistic regression, found that there is a positive significant association between environmental and financial performance [53].

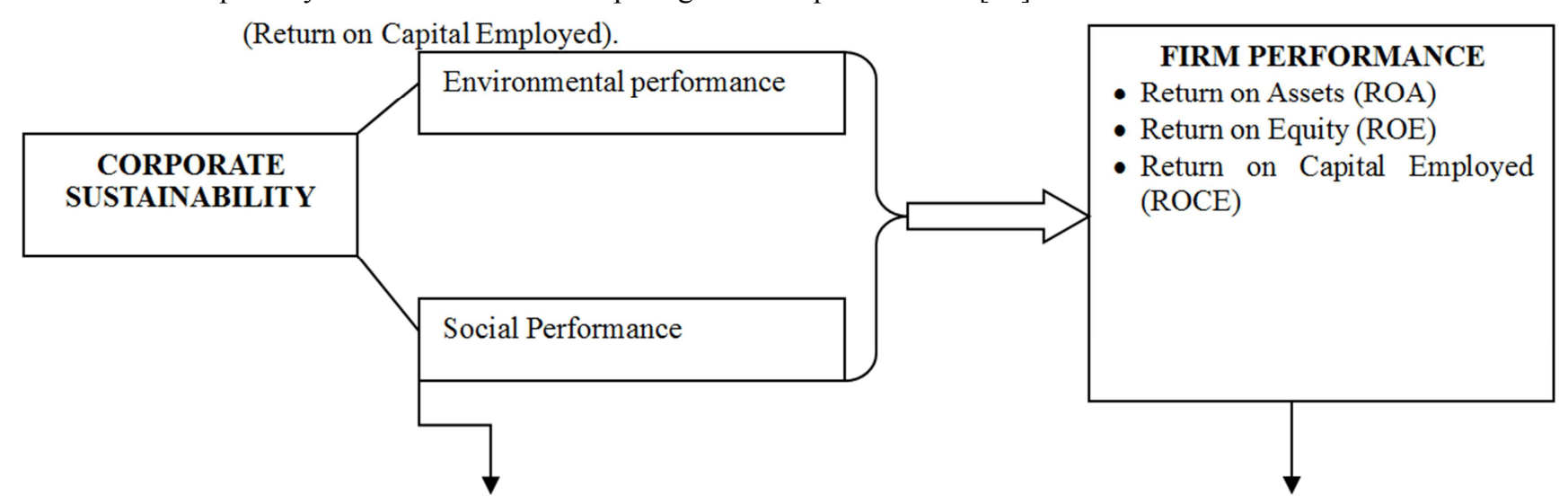

Figure 1. Relationship between Corporate Sustainability and Firm Performance.

The conceptual framework in Figure 1 above depicts the schematic representation of the expected causal relations among the dependent variable (firm performance) proxied using (i) Return on Assets, (ii) Return on Equity, and (iii)
Return on Capital Employed; and the independent variables (Corporate Sustainability) which consists of Environmental, and Social performance proposed for this study. 
Table 1. Major Events in the history of the Nigerian Oil and Gas.

\begin{tabular}{|c|c|}
\hline 1908 & Nigerian Bitumen Co. \& British Colonial Petroleum commenced operations around Okitipupa \\
\hline 1955 & Mobil Oil Corporation started operations in Nigeria \\
\hline 1956 & First successful well drilled at Oloibiri by Shell D'Arcy \\
\hline 1956 & Changed name to Shell-BP Petroleum Development Company of Nigeria Limited. \\
\hline 1958 & First shipment of oil from Nigeria. \\
\hline 1961 & $\begin{array}{l}\text { Shell's Bonny Terminal was commissioned. } \\
\text { Texaco Overseas started operations in Nigeria. }\end{array}$ \\
\hline 1962 & $\begin{array}{l}\text { Elf started operations in Nigeria. (As Safrap) } \\
\text { Nigeria Agip Oil Company started operations in Nigeria }\end{array}$ \\
\hline 1963 & $\begin{array}{l}\text { Elf discovered Obagi field and Ubata gas field } \\
\text { Gulf's first production }\end{array}$ \\
\hline 1965 & $\begin{array}{l}\text { Agip found its first oil at Ebocha } \\
\text { Phillips Oil Company started operations in Bendel State }\end{array}$ \\
\hline 1966 & Elf started production in Rivers State with $12,000 \mathrm{~b} / \mathrm{d}$ \\
\hline 1967 & $\begin{array}{l}\text { Phillips drilled its first well (Dry) at Osari -I } \\
\text { Phillips first oil discovery at Gilli-Gilli -I }\end{array}$ \\
\hline 1968 & $\begin{array}{l}\text { Mobil Producing Nigeria Limited) was formed. } \\
\text { Gulf's Terminal at Escravos was commissioned } \\
\text { Mobil started production from } 4 \text { wells at Idoho Field }\end{array}$ \\
\hline 1970 & $\begin{array}{l}\text { Agip started production } \\
\text { Department of Petroleum Resources Inspectorate started. }\end{array}$ \\
\hline 1971 & $\begin{array}{l}\text { Shell's Forcados Terminal Commissioned } \\
\text { Mobil's terminal at Qua Iboe commissioned }\end{array}$ \\
\hline 1973 & $\begin{array}{l}\text { First Participation Agreement; Federal Government acquires } 35 \% \text { shares in the Oil Companies. Ashland started PSC with then NNOC } \\
\text { (NNPC) } \\
\text { Pan Ocean Corporation drilled its first discovery well at Ogharefe-I }\end{array}$ \\
\hline & Second Participation Agreement, Federal Government increases equity to $55 \%$. \\
\hline 1974 & $\begin{array}{l}\text { Elf formally changed its name from "Safrap" } \\
\text { Ashland's first oil discovery at Ossu -I }\end{array}$ \\
\hline 1975 & $\begin{array}{l}\text { First Oil lifting from Brass Terminal by Agip } \\
\text { DPR upgraded to Ministry of Petroleum Resources }\end{array}$ \\
\hline 1976 & $\begin{array}{l}\text { MPE renamed Ministry of Petroleum Resources (MPR) } \\
\text { Pan Ocean commenced production via Shell-BP's pipeline at a rate of } 10,800 \mathrm{~b} / \mathrm{d}\end{array}$ \\
\hline 1977 & $\begin{array}{l}\text { Government established Nigerian National Petroleum Corporation (NNPC) by Decree 33, (NNOC \& MPR extinguished). } \\
\text { Third Participation Agreement (throughout NNPC) increases equity to } 60 \%\end{array}$ \\
\hline 1979 & $\begin{array}{l}\text { Fourth Participation Agreement; BP's shareholding nationalised, leaving NNPC with } 80 \% \text { equity and Shell } 20 \% \text { in the joint Venture. } \\
\text { Changed name to Shell Petroleum Development Company of Nigeria (SPDC) }\end{array}$ \\
\hline 1984 & Agreement consolidating NNPC/Shel1 joint Venture. \\
\hline 1986 & Signing of Memorandum of Understanding (MOU) \\
\hline 1989 & Fifth Participation Agreement; (NNPC $=60 \%$, Shell $=30 \%$, Elf $=5 \%$, Agip $=5 \%$ ). \\
\hline 1991 & $\begin{array}{l}\text { Signing of Memorandum of Understanding \& joint Venture Operating Agreement (JOA) } \\
\text { Production Sharing Contracts signed -SNEPCO }\end{array}$ \\
\hline 1993 & $\begin{array}{l}\text { Sixth Participation Agreement; (NNPC }=55 \% \text {, Shell }=30 \% \text {, Elf }=10 \% \text {, Agip }=5 \% \text { ). } \\
\text { The coming on-stream of Elf's Odudu blend, offshore OML } 100 \text {. }\end{array}$ \\
\hline 1995 & $\begin{array}{l}\text { SNEPCO starts drilling first Exploration well. } \\
\text { NLNG's Final Investment Decision taken }\end{array}$ \\
\hline 1999 & NLNG's First shipment of Gas out of Bonny Terminal \\
\hline 2000 & NPDC/NAOC Service Contract signed \\
\hline 2001 & $\begin{array}{l}\text { Production of Okono offshore field. } \\
\text { New PSCs agreement signed. }\end{array}$ \\
\hline 2002 & $\begin{array}{l}\text { Liberalisation of the downstream oil sector. } \\
\text { NNPC commences retail outlet scheme }\end{array}$ \\
\hline
\end{tabular}

Source: (www.oilandgasforum.com.ng/oil-gas).

\subsubsection{Sustainability Reporting Standards (GRI Standards)}

Several reporting standards exist as guidelines and frameworks for reporting sustainability. However, the Global reporting initiative (GRI) sustainability reporting standards is among the most widely accepted reporting standard for listed companies. The GRI Sustainability Reporting Standards (GRI Standards) are designed to be used by organizations to report about their impacts on the economy, the environment, and/or society. Among its mandate is to enhance the global comparability and quality of information on these impacts, thereby enabling greater transparency and accountability of organizations.

There are two different types of Standard Disclosures: i) general standard disclosures and ii) specific standard disclosures. Under the General Standard Disclosures, we have: i) Strategy and Analysis, ii) Organizational Profile, iii) Identified Material Aspects and Boundaries, iv) Stakeholder Engagement, v) Report Profile, vi) Governance, and vii) Ethics and Integrity. Under the Specific Standard Disclosures, we have: i) Disclosures on Management 
Approach, and ii) Indicators and Aspect-specific Disclosures on Management Approach. There are four major subcategories under the Specific Standard Disclosures:

Sub-Category: Labor Practices and Decent Work (employment, labour/management relations, occupational health and safety, training and education, diversity and equal opportunity, equal remuneration for women and men, Supplier assessment for labor practices, Labor Practices Grievance Mechanisms).

Sub-Category: Human Rights (Investment, Nondiscrimination, Freedom of Association and Collective Bargaining, Child Labor, Forced or Compulsory Labor, Security Practices, Indigenous Rights, Assessment, Supplier Human Rights Assessment, Human Rights Grievance Mechanisms)

Sub-Category: Society (Local Communities, Anticorruption, Public Policy, Anti-competitive Behavior, Compliance, Supplier Assessment for Impacts on Society, Grievance Mechanisms for Impacts on Society)

Sub-Category: Product Responsibility (Customer Health and Safety, Product and Service Labeling, Marketing Communications, Customer Privacy, Compliance)

The figure below shows an overview of the new GRI Standards:

\subsection{Review of Empirical Studies}

Amacha and Dastane [54] examined the relationship between sustainability practices and firm performance in the Malaysian Oil and Gas sector. Their specific objectives were to conduct a data analysis to understand the relationship between environmental, social and governance performance and financial performance which was measured using EBIT, EPS and PE ratio. Secondary data sources as sourced from a sample size of 21 oil and gas firms from 2011-2013. With the aid of a multiple regression model run via SPSS 21, there result shows that the majority of oil and gas companies in Malaysia had poor performance in terms of sustainability disclosure. On all three chosen profitability parameters (EBIT, EPS and PE ratio), the companies that practiced sustainability performed better than their counterparts that did not. Thus they conclude that a strong and significant relationship exists between sustainability practices and better financial performance.

Karlsson [18] analyzed the relationship between corporate sustainability performance and financial performance in Sweden. It also looked at the mediating effect of board diversity on the relationship between sustainability and firm performance. The study adopted a deductive approach using a multivariate regression method of analysis. The sample cumulatively amounted to 1,015 observations in a five-year period (2009-2013). His findings showed an incomplete positive relationship between corporate sustainability and financial performance as there are indications that the positive relationship is only true for low and moderate sustainability performers, and not for high sustainability performers. On the mediating effect of board diversity, he found that only educational board diversity have an impact on the relationship between sustainability and firm profitability.

Kipruto [55] studied the effect of corporate social responsibility on financial performance of commercial banks in Kenya. Financial performance was measured by use of net profits before taxes obtained from audited statements of comprehensive income. For uniformity purposes, net profits before taxes was chosen since some commercial banks had treated expenses on CSR as tax exempt while others had not. Investments were measured by considering loans to customers (except to other banks and corporations), investment in treasury bonds and government securities, investment in shares for trading purposes and investment in subsidiaries. Investment in CSR was measured using monetary spending on social activities. Data were obtained from commercial banks audited financial statements, websites, publications and annual reports. Commercial institutions that did not participate in CSR activities or that had not kept data pertaining to CSR were excluded. Secondary data from the year 2009 to 2013 was used for analysis. Using descriptive research design, the study tested for linear relationship between financial performance and corporate social responsibility. The study used multiple regression analysis and the five years secondary data to analyze the effect of corporate social involvement on financial performance. Financial performance was the dependent variable while corporate social responsibility and investments were the independent variables in the multi linear regression. The study revealed that not all commercial banks report their CSR involvement. Out of the 44 commercial banks studied, only eight provided the necessary and complete data that was appropriate for the study. The study findings were that expenses on social course have an effect on financial performance of commercial banks in Kenya.

Ameer and Othman [56] conducted an empirical study on the influence of sustainability practices on corporate financial performance of top global corporations in Malaysia. They proxied performance using sales/revenue growth, ROA, profit before tax and cash flows from operations. Using a quantitative and qualitative research design methods on a target population consisting of top 100 sustainable global companies in 2008 as selected from a universe of 3,000 firms from the developed countries and emerging markets; they find significant higher mean sales growth, return on assets, profit before taxation, and cash flows from operations in some activity sectors of the sample companies compared to the control companies over the period of 2006-2010. Their findings also show that the higher financial performance of sustainable companies has increased and been sustained over the sample.

In a study of Cortez and Cudia [57], they explored the impact of environmental innovations on financial performance of Japanese electronics companies following the growing literature linking corporate social performance with profitability. Using sample electronics companies listed in the Tokyo Stock Exchange, this industry study focuses on the 
global manufacturing leaders as they play a significant role in advancing environmental reporting due to their supplier networks and subsidiaries. Their findings point to risk minimization efforts of electronics companies in spite of declining profitability.

Cheung [58] analyzed the impacts (measured in terms of stock returns, risks and liquidity) of index inclusions and exclusions on corporate sustainable firms by studying a sample of US stocks that are added to or deleted from the Dow Jones Sustainability World Index over the period 2002 2008. Findings suggest that US investors do value CS, but in a temporary way.

Consolandi, Jaiswal-Dale, Poggiani and Vercelli [59] examined whether inclusion in, or deletion from, the Dow Jones Sustainability Stoxx Index (DJSSI), an index for European corporations, results in a stock market reaction. Their results, which namely show positive (negative) excess returns for companies included in (deleted from) the DJSSI over the period considered, suggest that the evaluation of the CSR performance of a firm is a significant criterion for asset allocation activities.

Lo and Sheu [60] examined whether corporate sustainability has an impact on market value using large US non-financial firms from 1999 to 2002. They used listing in the DJSGI USA as the proxy for corporate sustainability and the Tobin's q as the proxy for firm value. Their key finding is that sustainable firms are rewarded with higher valuations in the market place.

On the study Mehenna and Vernon [61] on environmental accounting: an essential component of business strategy. The paper examining the integration of environmental policy with business policy is the focus of this research. The paper found that the business firm's strategy includes responding to capital and operating costs of pollution control equipment. This is caused by increasing public concerns over environmental issues, and by a recent government-led trend to incentive-based regulation.

Mohammad, Sutrisno, Prihat and Rosidi [62] examined stakeholder theory and legitimacy as well as eco-efficient related to effect of environmental accounting implementation and environmental performance and environmental disclosure as mediation on company value. Samples are 59 companies that selected with purposive sampling technique. Analysis technique used is the Partial Least Square (PLS). Research results indicate that environmental accounting implementation is able to affect on company value, environmental information disclosure and on environmental information disclosure. However, environmental accounting implementation has not been able to affect on company value through environmental information disclosure, as well as environmental performance has not been able to affect company value through environmental information disclosure.

Schneider, Ghettas, Merdaci, Brown, Martyniuk, Alshehri, \& Trojan [63] evaluated the maturity of environmental, health and safety (EHS) efforts and progress toward sustainability in the oil and gas sector. Ten major oil companies have been analyzed based on public information including their published annual reports. Companies refer to voluntary initiatives when reporting their performance yet the assessment suggests that the sector overall continues to make progress and is maturing in its sustainability efforts. Many management system gaps were found that leave companies within this sector far from sustainable production and from being leaders in EHS Management. Most companies are still using lagging metrics and this is reflected in the activities implemented by companies. The sector's EHS management status is found to be in the high middle/medium level of maturity but with significant gaps in performance. This means that the sector has made progress from simply embracing sustainability towards a commitment to addressing sustainability issues, but still has progress to make particularly in compliance with the Clean Air Act, spill and process management.

Nnamani, Onyekwelu and Ugwu [64] evaluate the effect of sustainability accounting on the financial performance of listed manufacturing firms in Nigeria. Firms used for the study were chosen from the Nigerian brewery sector. Data were sourced from the financial statements of three sampled firms. Data were analysed using the ordinary linear regression. The study reveals that sustainability reporting has positive and significant effect on financial performance of firms studied.

Yahya and Ghodratollah [65] investigated the impact of corporate social responsibility disclosure (CSRD) on the financial performance of companies listed on the Tehran stock exchange, employing multiplelinear regression analysis. The CSRD was the independent variable as measured by economic, social and environmental while Return on Assets, Return on Equity and Price Earnings Ratio were used in measuring financial performance. The analysis produces inconsistent results.

Brian [66] used a normalized sustainability scoring system to examine the effects of sustainability reporting on firm value. In particular, this paper analyzes these effects during the Great Recession to note if there was any change in the effects on a year-by-year basis due to macroeconomic differences. This study finds that not only is superior corporate sustainability reporting positively correlated with increased firm value, but also that the degree of the impact greatly drops during the recession. These findings suggest that sustainability could be an advantageous business tool during stable economic times but not nearly as important in terms of increasing firm value during times of recession. Therefore, the results of this thesis have important practical uses and serve as a basis for analyzing the financial effects of corporate sustainability initiatives as this type of reporting becomes more prevalent in the future.

Lars, Henrik, \& Siv [67] investigated the effect of environmental information on the market value of listed companies in Sweden using a residual income valuation model. The results show that environmental responsibility as disclosed by sampled companies has value relevance, since it is expected to affect the future earnings of the listed 
companies. Their finding has implications for companies that pollute the environment-their future solvency may be eroded with gradual depletion in earnings.

Nnamani, Onyekwelu and Ugwu [2] evaluated the effect of sustainability accounting and reporting on financial performance (ROA) of listed manufacturing firms in Nigeria. They used secondary data sourced from the financial statements of three Nigerian brewery companies from 20102014. The study adopted the ex post -facto research design and used the ordinary linear regression for analysis. The result showed that sustainability reporting has positive and significant effect on financial performance of sampled firms.

Nwobu [15] examined the relationship between corporate sustainability reporting and profitability and shareholders fund in Nigerian Banks. The study sampled the annual reports of eight (8) banks in Nigeria for the presence or absence of sustainability reporting. The study adopted a content analysis methodology. The independent variables were proxied using Profit after Tax (PAT) and Shareholders Fund (SHF). Using a Pearson movement correlation matrix, the results of this study indicated that a small (weak) positive correlation $(\mathrm{r}=0.28)$ between sustainability reporting index and Profit after Tax (PAT). The study also found a small (weak) positive correlation $(\mathrm{r}=0.18)$ between sustainability reporting index and shareholders fund.

Enahoro [68] assessed the level of independence of tracking of costs impacting on the environment; level of efficiency and appropriateness of environmental costs and disclosure reporting. The research instruments utilized in the study were primary data survey and secondary data elucidation. For this purpose, cross-sectional and longitudinal content analyses were carried out. The test statistics applied in the study were the t-test statistics, Pearson ProductMoment correlation tests, ANOVA, and Multivariate Linear Regression Analysis. The study investigated best practice of environmental accounting among companies currently operating in Nigeria. Findings are that environmental operating expenditures are not charged independently of other expenditures. There is also, absence of costing system for tracking of externality costs. Environmental accounting disclosure does not however, take the same pattern among listed companies in Nigeria.

Ajayi and Ovwarhe [69] examined how Nigeria LNG uses CSR as a key strategy in creating an enabling environment that fosters support from all her stake holders which has led to good performance and growth of the company. This paper brought out CSR initiatives taken by NLNG in Nigeria that made her stands out as role model with regards to CSR in Nigeria. An exploratory research design was chosen in order to develop a profound understanding of the research topic and to obtain in-depth data about the research objectives. All main elements of the research paper, comprising theory, findings and analysis were incorporated in a cohesive and expository manner and structured in order to address and evaluate the central research objectives and hypotheses appropriately. The study conclude that the Corporate Social Responsibility of the Nigeria Liquefied Natural Gas has significant impact on the Nigerian Economy and employee organizational commitment and performance.

Olanyinka and Oluwamayowa [70] carried out a research on Corporate Environmental Disclosure and market value of Quoted Companies in Nigeria. The broad objective of this study was focused at ascertaining the aggregate and individual impact of Corporate Environmental Disclosure were regressed on market value. Descriptive research design was adopted and secondary data only was used. A sample size of fifty firms quoted in Nigeria Stock Exchange (NSE) was purposively selected for analysis based on the availability of environmental disclosures in their annual reports. The hypothesis was tested using correlation coefficient. The findings review that the inclusion of environmental disclosure will enhance market value. The study recommends that business should take caution in areas where environmental activities impacts negatively on the value of the firm and also invest in areas that enhance value for the firm.

Onyekwelu and Uche [71] carried out a research on Corporate Social Accounting and Enhancement of Information Disclosure among Firms in Nigeria. The broad object of this study was aimed at ascertaining if the inclusion of social accounting information in the financial statements will significantly enhance information disclosure. They adopted survey research design; primary and secondary data were used. A sample size of 108 was drawn from a total population of 148 using Taro Yamane formula. The research hypothesis was tested using chi square (X2). Finding reviews the inclusion and separate presentation of social costs incurred by organizations in the financial statements will enhance information disclosure in the statement.

Onyekwelu and Ekwe [72] examined whether corporate social responsibility predicate good financial performance using the banking sector in Nigeria. The study adopted the ex-post facto as it made use of historical research design and secondary data used. Analysis was done using the Ordinary Least Square Regression. The findings shows that the amount committed to social responsibility vary from one bank to the other. The data further revealed that the sample banks invested less than ten percent of their annual profit to social responsibility. The researchers recommended that companies. Nigeria particularly profitable one should give greater priority to Corporate Social Responsibility because this has the tendency to assist them to survive and maintain their profitability and also diffuse the tensions and hostilities usually experienced by companies in their localities.

Ekwueme, Egbunike and Onyali [11] examined the connection between such reporting practices and corporate performance from a stakeholder perspective. The study used a sample of 141 respondents, comprising 21 corporate managers; 55 corporate employees and 65 consumers and investors. Four hypotheses were formulated and tested in the study. In addition to descriptive statistics, KolmogorovSmirnov (K-S), One Sample t-test and Multiple Regression Technique (MRT) were used in analyzing the primary data. The results of the data analysis showed a positive connection 
between sustainability reporting and corporate performance. Both consumers and investors were inclined to product purchase of green corporations.

In a study by Okoye and Ezejiofor [12], their paper assesses the sustainability environmental accounting in enhancing corporate performance and economic growth. This study reviewed various forms including journal papers, articles and other relevant materials. This paper analyzed and tested two hypotheses with Pearson Product Movement Correlation Co-efficient. The study discovered that sustainable environmental accounting has significant impact on corporate productivity in order to enhance corporate growth.

Kasum and Osemene [73] assessed the Sustainable Development and Financial Performance of Nigerian Quoted Companies. The study was against the background that sustainable development practices usually involve financial outflows and hence, may be an unattractive investment to managers. They evaluated the impact of corporate compliance to accounting standards that are deemed to enforce sustainable development practices and can, therefore, imply sustainable development practices by companies, on the result of operations of companies. The study discovered that sustainable development practice of companies is rarely associated with financial performance over the years studied.

Ijeoma [74] determined the role of environmental cost accounting towards environmental sustainability in Nigeria. The source of data for this study is primary source of data collection with the aid of questionnaire. The research instrument was randomly administered to 200 respondents from organizations in Nigeria: Agricultural/Agro-Allied, Breweries, Chemical and Paints, Health Care/Pharmaceutical and Oil Marketing companies. The findings of the study revealed that majority of the respondents agreed that business organizations in Nigeria have not being aware of environmental policies. It was also found that that there exists no significant difference on business organizations in Nigeria not being aware of environmental policies.

Onyali, Okafor and Onodi [75] examined the effectiveness of triple bottom line disclosure practice of corporate firms in Nigeria by focusing on the perspective of corporate stakeholders. In achieving the above objective, three research questions were raised and two hypotheses were also formulated. The descriptive method of research design was employed to generate the required data. The population of the study was made up of three distinctive groups: Investors, Customers/Consumers and Accountants. The primary data were summarized using tables and the formulated hypotheses were analyzed using one-sample $\mathrm{z}$ test procedure done with the aid of SPSS version 22. Our findings indicated that investors and consumers expressed dissatisfaction with the extent of firms TBL disclosure practice in Nigeria. In their own view, most Organizations' reports were often vague and far from the expression of actual performance. Also, Accountants' were negative on the level of rigour and transparency exerted in the preparation of triple bottom line report by corporate firms in Nigeria.
Onyali, Okafor and Egolum [76] assessed the extent, nature and quality of environmental information disclosure practices of manufacturing firms in Nigeria. Content analysis was adopted in analyzing the annual report of the selected firms with regards to their environmental disclosure practices. Furthermore, a survey was carried out in order to ascertain whether the environmental disclosure practices of firms in Nigeria have improved. This was done with the aid of questionnaire administered to 40 Chartered accountants. The study adopted one sample t-test in testing the formulated hypothesis. The findings of the study indicated that the environmental disclosure practices of firms in Nigeria is still ad hoc and contains little or no quantifiable data.

This study explores the conceptualization of both the dependent (firm performance proxies) and independent (corporate sustainability dimensions) variables by analyzing the literature on the relationships between both categories of variables. The studies were reviewed in line with the title, scope, methodology and results from whence the research gap is identified. The review of the empirical studies indicates that the results of most of these researches are either inconclusive or contradictory with some reporting positive relationships (see Amacha \& Dastane, [54]; Dembo, [9]; Nnamani et al, [2]; Owolabi et al, [10]; Kwaghfan, [6]; Ekwueme et al [11]; Okoye and Ezejiofor, [12]; Albatayneh, [35]; Eccles et al, [45]; Ameer \& Othman, [56], others show negative and or no significant impact of sustainability reporting on financial performance (see Ezejiofor et al, [14]; Nwobu, [15]; Karlsson, [18]; Brian, [66]; Kasum et al, [16]; Lourenco et al, [1]). The evidences from these previous studies show that the relationship between corporate sustainability and firm performance have been grounded on empirical and theoretical arguments ranging from those that opine that sustainability practice reduces organizational profits, and those that suggest that it could be deployed for competitive advantage. The majority of the previous studies have been carried out in developed countries with far little attention been paid to such studies in developing countries like Nigeria. This study is therefore justified by assessing the impact of two of the three major dimensions of corporate sustainability (environment, and social) and firm's performance (using three different performance indicators) in the entire listed oil and gas companies in the Nigerian Stock Exchange. It is expected that the outcome would contribute in reconciling the inconsistencies in extant studies especially in the Nigerian context. This observed lack of convergence cumulating to the observed mixed results is an indication that this topic of study is far from been settled empirically, hence the need for more studies.

The few studies that focus on the oil and gas industry in Nigeria made use of only one dependent variable. This study is therefore justified by assessing the effect of two of the three major dimensions of corporate sustainability (environment and social) and firm's performance using three different performance indicators (dependent variables) in the entire listed oil and gas companies in the Nigerian Stock Exchange. It is expected that the outcome would contribute 
in reconciling the inconsistencies in extant studies especially in the Nigerian context.

\section{Methodology}

\subsection{Research Design}

Research design is the framework conceived to answer research questions or test hypotheses of a study (Avwokeni, 2016). The research design adopted for this study is an ex-post facto. The choice of this design is based on the nature of the study in which the researcher examined the effects of corporate sustainability reporting on firm performance.

\subsection{Population of the Study}

The population of this study consisted of the entire oil and gas firms listed on the Nigerian Stock Exchange (NSE) as at $31^{\text {st }}$ December, 2016. As at year ended $31^{\text {st }}$ December 2016, there are a total of fifteen (15) oil and gas firms listed in the Nigeria Stock Exchange (NSE) which comprises of:

Table 2. Population of Study.

\begin{tabular}{ll}
\hline S/N & Name Of Company \\
\hline 1 & Anino International \\
2 & Beco Petroleum Product \\
3 & Capital Oil \\
4 & Caverton Offshore Support Group \\
5 & Conoil Plc \\
6 & Eterna Plc \\
7 & Forte Oil (Ap) \\
8 & Japaul Oil \\
9 & Mobil Oil Nigeria \\
10 & Mrs Oil (Formerly Texaco, Chevron) \\
11 & Oando Plc (Formerly Unipetrol) \\
12 & Rak Unity Petroleum \\
13 & Seplat Petroleum Development \\
14 & Total Nigeria \\
15 & Navitus Energy \\
\hline
\end{tabular}

Source: Library of Nigeria Stock Exchange.

In terms of structure, the industry is broadly divided into upstream sector, downstream sector, and services sector. The study focuses on the downstream sector due to the public availability of their financial statements as majority are listed in the Nigerian Stock Exchange. The study period covered ten (10) financial years (2007-2016).

\subsection{Sample Size}

As a result, the "purposive sampling technique was applied (Non-random sample). In this method, the sample is chosen based on what the researcher thinks is appropriate for the study. A total of five (5) out of the fifteen (15) companies were inevitably excluded during the data collection process due to incomplete data. Consequently, what constituted the sample size of the study in a panel of one hundred (100) observations is ten (10).

\subsection{Data Analyses Techniques}

For the purpose of the empirical analysis, the study adopted descriptive statistics and regression analysis technique. A descriptive analysis of the data was conducted to obtain the sample characteristics and to observe the level of sustainability disclosure among the companies. The multiple regression analysis was performed to test the effect of the independent variables (corporate sustainability components) and corporate performance indicators. Some conventional diagnostic tests such as normality and autocorrelation tests were also conducted to address some basic underlying regression analysis assumptions.

Autocorrelation

This is used to ascertain the presence or absence of higher order correlation. Using Breusch-Godfrey Serial Correlation $\mathrm{LM}$ test, the decision rule is to reject the presence of autocorrelation if the Breusch-Godfrey Serial Correlation LM teststatistic probability value is greater than the norm (0.05), otherwise there is the presence of autocorrelation which tends to undermine the validity of the regression result.

Model Specification

In order to test for the relevance of the hypotheses regarding the impact of corporate sustainability on corporate firm performance of oil and gas companies listed on the Nigerian Stock Exchange, a multiple regression model was used as adopted from previous studies (Kwaghfan, 2015) which examines the relationship between dependent variables comprising of firm performance indicators and two or more regressors or independent variables (sustainability dimensions). The original model of Kwaghfan (2015) goes thus:

$$
\mathrm{Y}=\mathrm{b}_{0}+\mathrm{b}_{1} \mathrm{X} 1+\mathrm{b}_{2} \mathrm{X} 2+\mathrm{b}_{3} \mathrm{X} 3+\mathrm{e} \ldots \ldots \text {.Equ }
$$

Where: $\mathrm{Y}$ is the dependent variable describing four (4) corporate financial performance indicators namely; i) Return on asset, ii) Return on Equity, iii) Net profit margin; and iv) Earnings per Share.

e represents the error term which captures other possible explanatory variables not explicitly included in the model.

$b_{0}$ is the intercept of the regression.

$b_{1}, b_{2}$ and $b_{3}$ are the coefficients of the regression.

The above model was modified by the researcher to suit the specific objectives of this study.

Therefore, specified below are the adapted multiple regression econometric model used for the study which seeks to explain variations in the value of the dependent variable (firm financial performance) on the basis of changes in the independent variables (sustainability reporting). The assumption is that, the dependent variable is a linear function of the independent variable. The model is stated thus:

$$
\mathrm{Y}_{1}=f(\text { Corporate Sustainability }) \ldots \ldots \ldots . \mathrm{Equ}
$$

Where $\mathrm{Y}_{1}$ is the Corporate Firm performance (proxied using ROA, ROE, and ROCE,); while Corporate Sustainability was classified into one of its three main components which is Social sustainability performance. 
Thus, the three (3) proxies of firm financial performance culminated to three (3) multiple regression models as shown below:

$$
\begin{aligned}
& \mathrm{ROA}_{\text {it }}=\beta_{0}+\beta_{1} \mathrm{SOCP}_{\text {it }}+\mathrm{e}_{\mathrm{it}} \ldots \ldots \ldots \ldots . \mathrm{Equ} \\
& \mathrm{ROE}_{\mathrm{it}}=\beta_{0}+\beta_{1} \mathrm{SOCP}_{\mathrm{it}}+\mathrm{e}_{\mathrm{it} . \ldots \ldots \ldots . . \mathrm{Equ}} \\
& \mathrm{ROCE}_{\mathrm{it}}=\beta_{0}+\beta_{1} \mathrm{SOCP}_{\mathrm{it}}+\mathrm{e}_{\mathrm{it}} \ldots \ldots . \mathrm{Equ}
\end{aligned}
$$

Where:

$\beta_{0}=$ represents the constant or intercept

$\beta_{1}$ to... $\beta_{2}=$ represents estimated parameters

$\mathrm{e}_{\mathrm{it}}=$ represents the error term

$\mathrm{ROA}_{\text {it }}=$ Return on Asset of company $i$ in year $t$

$\mathrm{ROE}_{\text {it }}=$ Return on Equity of company $i$ in year $t$

$\mathrm{ROCE}_{\mathrm{it}}=$ Return on Capital Employed of company $i$ in year $t$

$\mathrm{SOCP}_{i t}=$ Social Sustainability Performance disclosure of company $i$ in year $t$

Our apriori expectations were projected as follows: $\beta_{1}>0$, $\beta_{2}>0$ (i.e. in each of the model), which means that:

$\mathrm{B}_{1}>0$ : implies that increase in the social performance is expected to lead to an increase in ROA and indeed, ROE and ROCE.

\section{Data Presentation and Analysis}

\subsection{Regression Diagnostic Tests}

Several underlying diagnostic tests were conducted prior to the estimation to ensure that the basic regression analysis assumptions are not violated. The tests include: Normality test using the JargueBera, Variance Inflation Factor (VIF) for Multicollinearity, White Heteroskedasticity test and the LM test for autocorrelation.

\subsection{Test of Hypotheses}

The six null hypotheses earlier formulated in the first chapter of this study were tested in this sub-section. The probability (sig.) values obtained from the regression result were used for the tests. The decision rule goes thus: the null hypothesis will be accepted if the probability value ( $p$-value) is greater than 0.05 or when the calculated t-statistics is less than 2.0, or reversely we accept the alternative (i.e. if the probability ( $p$-value) value becomes less than 0.05 and or the $\mathrm{t}$-statistics is $\geq 2$.

Test of hypothesis one

Ho: Corporate social sustainability reporting does not significantly affect Return on Assets (ROA) of Oil and Gas Companies listed on the Nigerian Stock Exchange.

Table 3. Test summary for hypothesis one.

\begin{tabular}{lllllll}
\hline & Dependent Variable(s) & Independent Variable & t-statistics & p-value (Sig.) & Significant or not & Decision \\
\hline Ho & Return on Assets (ROA) & $\begin{array}{l}\text { Social sustainability } \\
\text { reporting }\end{array}$ & -0.952838 & 0.3431 & NSig \\
\hline
\end{tabular}

Source: Researchers Compilation (2018) NSig = Not significant.

*Significant at 5\% (95\%) level of confidence.

Interpretation: The above test result shows that the effect of social sustainability reporting on return on assets (ROA) is not significant and the p-value of 0.3431 is greater than 0.05 . This led to the acceptance of the null hypotheses (Ho). Thus, we conclude that "corporate social sustainability reporting does not significantly affect Return on Assets (ROA) of Oil and Gas Companies listed on the Nigerian Stock Exchange".

Test of hypothesis two

Ho: Corporate social sustainability reporting does not have a significant effect on Return on Equity (ROE) of Oil and

\begin{tabular}{|c|c|c|c|c|c|c|}
\hline & Dependent Variable(s) & Independent Variable & t-statistics & p-value (Sig.) & Significant or not & Decision \\
\hline Ho & Return on Equity (ROE) & Social sustainability reporting & -2.552775 & $0.0123 *$ & Sig & Reject null \\
\hline
\end{tabular}
Gas companies listed on the Nigerian Stock Exchange.

Table 4. Test summary for hypothesis two.

Source: Researchers Compilation (2018) NSig = Not significant.

*Significant at 5\% (95\%) level of confidence.

Interpretation: The above test result shows that the effect of social sustainability reporting on return on equity (ROE) is significant and the p-value of 0.0123 is less than 0.05 . This led to the rejection of the null hypotheses (Ho) and acceptance of the alternative hypothesis $\left(\mathrm{H}_{\mathrm{I}}\right)$. Thus, we conclude that "Corporate social sustainability reporting has a significant effect on the Return on Equity (ROE) of Oil and Gas companies listed on the Nigerian Stock Exchange".

Test of hypothesis three

Ho: Corporate social sustainability reporting does not have a significant effect on Return on Capital Employed (ROCE) of Oil

\begin{tabular}{|c|c|c|c|c|c|c|}
\hline & Dependent Variable(s) & Independent Variable & t-statistics & p-value (Sig.) & Significant or not & Decision \\
\hline Ho & $\begin{array}{l}\text { Return on Capital Employed } \\
\text { (ROCE) }\end{array}$ & $\begin{array}{l}\text { Social sustainability } \\
\text { reporting }\end{array}$ & -0.502204 & 0.6167 & NSig & Accept null \\
\hline
\end{tabular}
and Gas companies listed on the Nigerian Stock Exchange.

Table 5. Test summary for hypothesis three.

Source: Researchers Compilation (2018) NSig = Not significant.

*Significant at $5 \%(95 \%)$ level of confidence. 
Interpretation: The above test result shows that the effect of social sustainability reporting on return of capital employed (ROCE) is not significant and the p-value of 0.6167 is greater than 0.05 . This led to the acceptance of the null hypotheses (Ho). Thus, we conclude that
"Corporate social sustainability reporting does not have a significant effect on Return of Capital Employed (ROCE) of Oil and Gas companies listed on the Nigerian Stock Exchange"

\subsection{Presentation of Results}

Table 6. Descriptive Statistics of Dependent and Independent variables.

\begin{tabular}{|c|c|c|c|c|}
\hline & ROA & ROE & ROCE & SOCP \\
\hline Mean & 0.020184 & 0.015537 & 5.420841 & 0.180564 \\
\hline Median & 0.035141 & 0.132420 & 6.362373 & 0.166667 \\
\hline Maximum & 0.303097 & 0.907611 & 28.56445 & 0.461806 \\
\hline Minimum & -0.71357 & -3.93969 & -52.184 & 0.041667 \\
\hline Std.Dev. & 0.125952 & 0.729498 & 11.24324 & 0.074079 \\
\hline Skewness & -2.59336 & -3.55869 & -2.21056 & 0.837219 \\
\hline Kurtosis & 14.97243 & 17.30371 & 11.45862 & 4.320600 \\
\hline Probability & 0.000000 & 0.000000 & 0.000000 & 0.000077 \\
\hline Sum & 2.018369 & 1.553710 & 542.0841 & 18.05642 \\
\hline SumSq.Dev. & 1.570516 & 52.68451 & 12514.64 & 0.543287 \\
\hline Observations & 100 & 100 & 100 & 100 \\
\hline
\end{tabular}

Source:Eviews 9 out put (2018).

Table 6 shows the descriptive statistics of the sustainability and performance measures that formed the independent and dependent variables used in the study. As observed, an overall average of $2.01 \%$ of ROA (return on assets) with a maximum average of about $30.31 \%$ is an indication of an increasing profit earnings margin in relation to the overall resources of the sampled firms.

Similarly, the mean value of ROE was slightly lower at 0.015537 which also indicates an overall positive trend on the sampled firm's ability managing the shareholders funds towards profit generation. The return on capital employed (ROCE) showed a high mean value of 5.420841 which indicates that the sampled companies optimally manages its equity and debt towards profit generation. This is a sign of a progressively growing sector.

It was also noted that the three performance ratios all have negative minimal values; this suggests that not all the sampled companies generated enough income compared to the capital they invested during the period under review.

Also, the standard deviations of all the performance measures are observed to be largely small and not too far from the mean, this indicates that the performance indices among the sampled companies did not disperse $( \pm)$ much across the distribution. Further, the variable of SOCP (social sustainability performance) showed mean values of 0.180564 and 0.079669 respectively. This shows that, on average, the overall sampled companies disclosed only about $18.06 \%$ of the entire required social sustainability disclosure requirements, while only about $7.97 \%$ was disclosed on the required environment sustainability disclosure index. What his implies is that, generally, the entire sample can be classified as low sustainability companies. This appears to support the findings of Owolabi et al (2016) which found the overall sustainability reporting of a Nigerian manufacturing industry to be $15 \%$ and attributed the poor disclosure to the non-mandatory nature of the practice. It was also observed that there is wide dispersion in the variable of SOCP (with a standard deviation value of 0.07 ) which further highlights an uneven spread of adherence to social sustainability reporting among the sampled companies.

On the normality status of the individual variables, the result showed that the variable of SOCP fairly symmetrical and moderately skewed as their skewness and kurtosis values stood between -0.5 and 1 . The remaining variables (ROA, ROE and ROCE) showed high Jarque-Bera values (709.34, 1063.56 and 379.56 respectively) indicating significantly departure from normality. These can be attributed to the small nature of the sample observation considering the limited number of listed oil and gas firms.

\subsection{Regression Results}

The overall statistical significance of the models are assured at the $5 \%$ level owing to the f-statistics values of 3.3, 3.1 and 3.36 for model one, two and three respectively. This shows that, taken together, there is a linear relationship among the variables. On the percentage of the variations in ROA, ROE and ROCE that was accounted for by the two sustainability proxies (independent variables) taken together, the result showed a total of $12.2 \%, 8.1 \%$ and $12.4 \%$ respectively for each of the three models. The individual values of the adjusted R-squared which controls for the effect of the inclusion of successive explanatory variables on the degrees of freedom stood at about $8.5 \%$ (for model one), $4.2 \%$ (model two) and $8.7 \%$ for model three. This implies that a significant proportion of variances in the performance proxies (dependent variables) were not captured by the model meaning that other factors not captured by the model explain a larger proportion of those variations. Implicationally, the 
models can be said to have low explanatory powers.

Further, a look at the slope coefficients of the independent variables of the three models shows that SOCP will most likely exert a negative impact on the three performance proxies (ROA, ROE and ROCE) used as dependent variables. However, while SOCP effect on ROA and ROCE are statistically insignificant, its effect on ROE passed the significant test at 5\% levels due to its (SOCP) probability value of 0.01 in model two. Thus, a unit increase in social sustainability (SOCP) will lead to about 2.55 units significant decreases in return on equity (ROE).

\section{Conclusion and Recommendations}

\subsection{Conclusion}

The study empirically examined the extent of sustainability reporting among the oil and gas companies listed in the Nigerian Stock Exchange (NSE). The major focus was to find out how social and environmental sustainability affects the performance of the sampled firms. The items of the social and environmental sustainability disclosure assessment are based on a content analysis using the GRI-G4 implementation manual (2015d), while performance measures adopted included are return on assets (ROA), return on equity (ROE) and return on capital employed (ROCE).

On the result of the regression analysis, the study found that while the social aspect of sustainability have overall negative effect on all the three profit performance proxies. In general, out of the three research hypotheses tested, only hypothesis two $\left(\mathrm{Ho}_{2}\right)$, the only variable of interest is return on equity which was significantly affected by social sustainability performance. The other two financial performance proxies (ROA and ROCE) were not significantly affected by social sustainability. This indicates that; sustainability reporting practices of the Nigerian oil and gas companies does not strongly affect their performance, all things being equal, it shows that in terms of the effects of corporate social sustainability on the financial performanceindicators of the oil and gas companies in Nigeria, the poor level of sustainability disclosures observed, it can be concluded that the oil and gas companies in Nigeria are low sustainability companies.

\subsection{Recommendations}

Based on the findings of this study, the followings were recommended:

The relevant regulatory authorities should encourage sustainability reporting practices among Nigerian companies by aligning the existing global sustainability standards to reflect the social and environmental challenges peculiar in the Nigeria context.

Despite the fact that sustainability reporting is still an evolving concept in Nigeria, its compliance level among companies can be rapidly enhanced if it is made mandatory to a specified magnitude rather than its current voluntary-nature.

\section{References}

[1] Lourenco, I. C., Branco, M. C., Curto, J. D. \& Eugenio, T. (2012). How does the market value corporate sustainability performance? Journal of Business Ethics, 10 (8), 417-428.

[2] Nnamani, J. N., Onyekwelu, U. L. \& Ugwu, O. K. (2017). Effect of sustainability accounting and reporting on financial performance of firms in Nigeria brewery sector. European Journal of Business and Innovation Research, 5 (1), 1-15.

[3] PricewaterhouseCoopers (2016). Corporate sustainability definition and challenges. Retrieved on July 2nd, 2017 from: http: //www.csrquest.net/default.aspx? articleID=13113.

[4] Asaolu, T. O., Agboola, A. A., Ayoola, T. J. \& Salawu, M. K. (2011). Sustainability reporting in the Nigerian oil and gas sector. Proceedings of the environmental management conference, Federal University of Agriculture, Abeokuta, Nigeria.

[5] Ejoh, N. O., Orok, E. O. \& Sackey, J. A. (2014). The development of environmental accounting and disclosure practices of manufacturing companies in Nigeria. Journal of Sustainable Development, 5 (12), 70-79.

[6] Kwaghfan, A. (2015). Impact of sustainability reporting on corporate performance of selected quoted companies in Nigeria. (published doctoral dissertation). Department of Accountancy, University of Nigeria, Enugu.

[7] Uwaoma, I., \& Ordu, P. A. (2016). Environmental reporting in the oil and gas industry in Nigeria. International Journal of Research in Business Studies and Management, 3 (11), 1-21.

[8] Uwuigbe, U. \& Jimoh, J. (2012). Corporate environmental disclosures in the Nigerian manufacturing industry: A study of selected firms. An International Multidisciplinary Journal, 6 (3), 71-83.

[9] Dembo A. M. (2017) The Impact of Sustainability Practices on the Financial Performance: Evidence from Listed Oil and Gas Companies in Nigeria. In: Capaldi N., Idowu S., Schmidpeter R. (eds) Dimensional Corporate Governance. CSR, Sustainability, Ethics \& Governance. Springer, Cham.

[10] Owolabi, F., Akinwumi, T., Adetula, D. \& Uwuigbe, U. (2016). Assessment of sustainability reporting in Nigerian industrial goods sector. Paper presented at 3rd International Conference on African Development Issues. Covenant University, Otta, Ogun State, Nigeria.

[11] Ekwueme, C. M., Egbunike, C. F. \& Onyali, C. I. (2013). Benefits of triple bottom line disclosures on corporate performance: An exploratory study of corporate stakeholders, Journal of Management and Sustainability, 3 (5), 79-91.

[12] Okoye, P. V. C. \& Ezejiofor, R. A. (2013). An appraisal of sustainability environmental accounting in enhancing corporate productivity and economic performance. International Journal of Advanced Research, 1 (8), 685-693.

[13] Bassey, E. B., Oba, U. E. U, \& Onyah, G. E., (2013). An analysis of the extent of implementation of environmental cost management and its impact on output of oil and gas companies in Nigeria, (2001-2010). European journal of business and Management, 5(1), 110-117. 
[14] Ezejiofor, R. A., Racheal, J. A. \& Chigbo, C. E. (2016). Effect of sustainability environmental cost accounting on financial performance of Nigerian corporate organizations. International Journal of Scientific Research and Management, 4 (8), 4536-4549.

[15] Nwobu, O. (2015). The relationship between corporate sustainability reporting and profitability and shareholders fund in Nigerian banks. Journal of Accounting and Management, 5 (3), 1-12.

[16] Kasum, A. S., Osemene, O. F., Olaoya, J. A., Aliu, A. O. \& Abdulsalam, T. S. (2011). Sustainable development and performance, financial position and market value of Nigerian quoted companies. Journal of Economics and Sustainable Development, 2 (4), 20-33.

[17] Ogundare, E. A. (2013). The impact of sustainability reporting on organisational performance-The Malaysia experience. International Journal of Accounting Business and Management, 1 (1), 2289-2717.

[18] Karlsson, J. (2015). Corporate sustainability and financial performance - The influence of board diversity in a Swedish context. (published Master's thesis). Department of Business Studies, Uppsala University. Sweden.

[19] Bansal, P. \& DesJardine, M. R. (2014). Business sustainability: It is about time. Strategic Organization, 12 (1), 70-78.

[20] White, M. A. (2013). Sustainability: I know it when I see it. Ecological Economics, vol. 86, pp. 213-217.

[21] Mohammad, I., Sutrisno, T., Prihat, A., \& Rosid (2013). Effect of environmental accounting implementation and environmental performance and environmental information disclosure as mediation on company value. International journal of business and management invention ISSN (Online): 2319-8028, ISSN (Print): 2319-801X www.ijbmi.org 2 (1).

[22] Laverty, K. J. (1996). Economic 'short-termism': The debate, the unresolved issues, and the implications for management practice and research. The Academy of Management Review, $21(3), 825-860$.

[23] Porter, M. E. \& Kraemer, M. R. (2011). Creating shared value. Harvard Business Review, 89 (1-2), 62-77.

[24] GRI. (2013). The sustainability content of integrated reports-a survey of pioneers. Research \& development series, 58 .

[25] Friedman, M. (1970, September). The social responsibility of business is to increase its profits. New York Times Magazine, $13,32-33$.

[26] Nze, D. O., Okoh., J. \& Ojeogwu, I. C (2016). Effect of Corporate Social Responsibility on earnings of quoted firms in Nigeria. ESUT Journal of Accountancy (1) 260-267 [27] Murray, A. T. (2010). Quantitative geography: Journal of Regional Science. Retrieved fromhttp: //onlinelibrary.wiley.com/doi/10.1111/j.1467 787.2009.00642.x/abstract

[27] Kwanbo, M. L. (2011). An assessment of the effectiveness of social disclosure on earnings per Share in Nigerian public corporations. World Journal of Social Sciences, 1 (1), 86-106.

[28] Hamilton, S. Jo. H. \& Statman, M. (1993). Doing well while doing good? The investment performance of socially responsible mutual funds. Financial Analysts Journal. 21, 102.
[29] McWilliams, A., Siegel, D. \& Wright, P. M. (2006). Corporate social responsibility: Strategic implications. Journal of Management Studies, 43 (1), 1-18.

[30] Waddock, S. A. \& Graves, S. B. (1997). The corporate social financial performance link. Strategic Management Journal, 18 (4), 303-319.

[31] Helg, A. (2007). Corporate social responsibility from a Nigerian perspective. (unpublished master's thesis). Department of economics, university of Gothenburg, Sweden.

[32] Onwuegbuchi, C. (2009). Telecom operators as socially responsible organisations. Nigeria Communications Week. 5, 22

[33] Dabbas, M. \& Al-rawashdeh, S. T. (2012). The effect of corporate social responsibility on the profitability of the industrial companies in Jordan. Canadian Social Science, 8 (3), 32-37.

[34] Alkababji, M. W. (2014). Voluntary disclosure on corporate social responsibility: A study on the annual reports of Palestinian corporations. European Journal of Accounting Auditing and Finance Research, 2 (4), 59-82.

[35] Horne, J. V. \& Wachowicz, J. (2005). Fundamentals of financial management. (12th ed.) New Delhi: Pearson Education.

[36] Ross, S. A., Westerfield, R.W. \& Jaffe, J. (2005). Corporate finance. (7th ed.). New York. McGraw-Hill Inc.

[37] Barnett, M. L. \& Salomon, R. M. (2012). Does it pay to be really good? Addressing the shape of the relationship between social and financial performance. Strategic Management Journal, 33 (11), 1304-1320.

[38] Lopez, M. V., Garcia, A. \& Rodriguez, L. (2007). Sustainable development and corporate performance: A study based on the Dow Jones sustainability index. Journal of Business Ethics, 75 (3), 285-300.

[39] Epps, R. \& Cereola, S. J. (2008). Do institutional shareholder services (ISS) corporate governance ratings reflect a company's operating performance? Critical Perspectives on Accounting, 19, $1135-1148$.

[40] Gozali, N. O., How, J. C. Y. \& Verhoeven, P. (2002). The economic consequences of voluntary environmental information disclosure. International congress on environmental modelling and software. 263.

[41] Buys, P., Oberholzer, M. \& Andrikopoulos, P. (2011). An investigation of the economic performance of sustainability reporting companies versus non-reporting companies: A South African perspective. Journal of Social Sciences, 29 (2), 151-158.

[42] Gregory, A., Tharyan, R. \& Whittaker, J. (2011). Corporate social responsibility and company value. Journal of business ethics. 124, 633-657.

[43] Ngwakwe, C. C. (2009). Environmental responsibility and firm performance: Evidence from Nigeria. International Journal of Human and Social Sciences, 4 (6), 384-391.

[44] Eccles, R. G., Ioannou, I. \& Serafeim, G. (2012). The impact of corporate sustainability on organizational processes and performance. Working Paper. Harvard Business School. $\begin{array}{lllll}\text { Retrieved on July 9, } 2017 \text { from } & \end{array}$ http://ssrn.com/abstract=1964011.

[45] Roberts, W. P. \& Dowling, R. G. (2002). Corporate reputation and sustained superior financial performance. Strategic Management Journal, 23, 1077-1093. 
[46] Adam, C., \& Zutshi, A. (2004). Corporate social responsibility: Why business should act responsibly and be accountable. Australian Accounting Review, 14 (3), 31-39.

[47] Olayinka, M. U. \& Temitope, O. F. (2011). Corporate social responsibility and financial performance in developing Economies. The Nigerian Experience. New Orleans, New Orleans International Academic Conference, 815-824.

[48] Yahya, H. Y. \& Ghodratollah, B. (2014). The effect of disclosure level of CSR on corporate financial performance in Tehran stock exchange. International Journal of Accounting Research, 1 (11): 43-51.

[49] Pandey, I. M. (2004). Financial Management. (7th ed.) New Delhi: VIKAS Publishing House, PVT Ltd.

[50] Kurucz, E., Colbert, B. \& Wheeler, D. (2008). The business case for corporate social responsibility. Oxford: Oxford University Press.

[51] Margolis, J. D., Elfenbein, H. A. \& Walsh, J. P. (2007). Does it pay to be good? A meta-analysis and redirection of research on the relationship between corporate social and financial performance. Working Paper, Harvard Business School, Boston, MA $02163-7819$.

[52] Oba, V. C., Fodio, M. I. \& Soje, B. (2012). Value relevance of environmental responsibility information disclosure in Nigeria. Acta Universitatis Danubius Economica, 8 (6), 100-113.

[53] Amacha, E. B., \& Dastane, O. (2017). Sustainability practices as determinants of financial performance: A Case of Malaysian Corporations. Journal of Asian Finance, Economics and Business, 4 (2), 55-68.

[54] Kipruto, D. (2014). The effect of corporate social responsibility on financial performance.

[55] Ameer, R. \& Othman, R. (2012). Sustainability practices and corporate financial performance: A study based on the top global corporations. Journal of Business Ethics, 10 (8), 1-19.

[56] Cortez, M. A. A. \& Cudia, C. P. (2011). Sustainability innovations and the impact on financial performance of Japanese automotive and electronics companies. College of international management, Ritsumeikan Asia Pacific University, 1-1 Jumonjibaru, Beppu, Oita 8740919.

[57] Cheung, A. (2011). Do stock investors value corporate sustainability? Evidence from an event study. Journal of Business Ethics, 99 (2), 145-165.

[58] Consolandi, C., Jaiswal-Dale, A. Poggiani, E. \& Vercelli, A. (2009). Global standards and ethical stock indexes: The Case of the Dow Jones sustainability stoxx index. Journal of Business Ethics, 87, 185-197.

[59] Lo, S. \& Sheu, H. (2007). Is corporate sustainability a valueincreasing strategy for business? Corporate Governance, 15 (2), 345-358.

[60] Mehenna, Y. \& Vernon, P. D. (2004). Environmental accounting: An essential component of business strategy. Business Strategy and the Environment. 13 (2), 65-77.

[61] Mohammad, I., Sutrisno, T., Prihat, A. \& Rosid, N. (2013). Effect of environmental accounting implementation and environmental performance and environmental information disclosure as mediation on company value. International Journal of Business and Management Invention, 2 (1), 55-67.
[62] Schneider, J., Ghettas, S., Merdaci, N., Brown, M., Martyniuk, J., Alshehri, W. \&Trojan, A. (2013). Towards sustainability in the oil and gas sector: Benchmarking of environmental, health, and safety efforts. Journal of Environmental Sustainability: 3 (3).

[63] Nnamani, J. N., Onyekwelu, U. L., \& Ugwu, O. K. (2017). Effect of sustainability accounting and reporting on financial performance of firms in Nigeria brewery sector. European Journal of Business and Innovation Research 5 (1), pp.1-15, February 2017.

[64] Yahya, H. Y., \& Ghodratollah, B. (2014). The effect of disclosure level of CSR on corporate financial performance in Tehran stock exchange, International Journal of Accounting Research, 1 (11): 43-51.

[65] Brian, D. B. (2012). The effect of corporate sustainability reporting on firm valuation. CMC Senior Theses. Paper 489. http: //scholarship.claremont.edu/cmc_theses/489.

[66] Lars, H., Henrik, N. \& Siv, N. (2005). The value relevance of environmental performance: European Accounting Review, 14 (1), 41-61.

[67] Enahoro, J. A. (2009). Design and bases of environmental accounting in oil \& gas and manufacturing sectors in Nigeria. (unpublished master's thesis). department of accounting, Covenant university, Nigeria, Ota.

[68] Ajayi, S. D. \& Ovwarhe, L. U. (2016). The effect of corporate social responsibility on the performance and growth of the oil \& gas Industry in Nigeria: A case study of Nigeria LNG Limited, Social Science Research Network. Retrieved from http: //papers.ssrn.com/sol3/papers.cfm?abstract_id=2745079.

[69] Olayinka, O. A. \& Oluwamayowa, O. (2014). Corporate environmental disclosures and market value of quoted companies in Nigeria. The Business and Management Review, $5(4), 171-184$

[70] Onyekwelu, U. L. \& Uche, U. B. (2014). Corporate social accounting and the enhancement of information disclosure among firms in Nigeria: A case of some selected firms in Nigeria. Journal of Economics and Sustainable Development, 5 (6), 35-44.

[71] Onyekwelu, U. L. \& Ekwe, M. C. (2015). Does corporate social responsibility predicate good financial performance? Evidence from the Nigeria banking sector. Research Journal of Finance and Accounting, 6 (17), 30-41.

[72] Kasum, A. S. \& Osemene, O. F. (2010). Sustainable development and financial performance of Nigerian quoted companies. (unpublished master's thesis).Department of Accounting and Finance, University of Ilorin, Ilorin, Nigeria.

[73] Ijeoma N. B. (2015). The role of environmental cost accounting in environmental sustainability in Nigeria. American Journal of Business, Economics and Management. 3 (6), 395-407.

[74] Onyali, C. I., Okafor, T. G. \& Onodi, E. (2015). Effectiveness of triple bottom line disclosure practice in Nigeria: Stakeholders perspective. European Journal of Accounting Auditing and Finance Research 3 (3), 45-61.

[75] Onyali, C. I., Okafor, T. G. \& Egolum, P. (2014). An assessment of environmental information disclosure practices of selected Nigerian manufacturing companies. International Journal of Finance and Accounting, 3 (6), 349-355. 